\title{
An Experimental Investigation and Aspen HYSYS Simulation of Waste Polystyrene Catalytic Cracking Process for the Gasoline Fuel Production
}

\author{
Selvaganapathy Thambiyapillai ${ }^{* *}$ and Muthuvelayudham Ramanujam ${ }^{b}$
}

${ }^{a}$ Tamilnadu Pollution Control Board (TNPCB), Tamilnadu, India.

${ }^{b}$ Department. of Chemical Engineering, Annamalai University, Chidambaram, Tamilnadu, India.

\begin{abstract}
Plastic wastes are necessary to recycle due to their disposal issues around the world. They can be recycled through various techniques i.e., mechanical reprocessing, mechanical recycling, chemical recycling and incineration. Most recycling techniques are expensive and end up in producing low-grade products excluding chemical recycling; it is an eco-friendly way to deal with plastic waste. Catalytic cracking is one of the chemical recycling methods, for converting waste plastics into liquid fuel same as commercial fuels. An experimental investigation of polystyrene catalytic cracking process was conducted with impregnated fly ash catalyst and $88.4 \%$ of liquid product yield was found as a maximum at optimum operating conditions $425^{\circ} \mathrm{C}$ and $60 \mathrm{~min}$. The liquid fuel quality was analyzed using FTIR spectra analysis, GC/MS analysis and Physico-chemical property analysis. The GC/MS analysis shows that the fly ash cracking of polystyrene leads to the production of gasoline fuels within the hydrocarbon range of C3-C24, and the aliphatic and aromatic functional compounds were detected using FTIR analysis. Moreover, the Aspen Hysys simulation of polystyrene catalytic cracking was conducted in a pyrolytic reactor at $425^{\circ} \mathrm{C}$ and at the end of the simulation, $93.6 \%$ of liquid fuel yield was predicted. It was inferred that the simulation model for the catalytic cracking is substantial to fit the experimental data in terms of liquid fuel conversion.
\end{abstract}

Keywords: Catalytic cracking; Polystyrene; Aspen Hysys simulation; Fly ash; Gasoline fuels; FTIR.

Article History: Received: 29th Oct 2020; Revised: 22 ${ }^{\text {nd }}$ April 2021; Accepted: $5^{\text {th }}$ July 2021; Available online: $20^{\text {th }}$ July 2021

How to Cite This Article: Thambiyapillai, S. and Ramanujam, M. (2021) An Experimental Investigation and Aspen HYSYS Simulation of Waste Polystyrene Catalytic Cracking Process for the Gasoline Fuel Production. Int.JournalofRenewable Energy Development, 10(4),891-900 https://doi.org/10.14710/ijred.2021.33817

\section{Introduction}

The recent research activity across the world focusing on plastic waste management. The generation of plastic in solid waste is a major environmental issue which exist in metric tons worldwide. Plastic waste has increased drastically due to its reliability and scope of applications in various sectors such as agriculture, construction, households, packaging, automobile, aerospace manufacturing, etc., (Amoodi et al. 2013). The generation of plastic waste has gone up exponentially on a worldwide scale since 1950 and has reached around 150 metric tons per annum all-inclusive (Cleetus et al., 2013). In the upcoming decades, around 300 million tons of plastic waste would be emanated each year which corresponds to the equivalence of world human population (Saxena et al., 2017). The plastic waste generation in India during 20182019 was estimated as 3360043 tons per annum (Annual Report-Ministry of Housing and Urban Affairs 2019). Around $50-70 \%$ of plastic wastes being packaging items mostly contained recyclable plastics such as polyethylene (PE), polypropylene (PP), polystyrene (PS), and polyvinyl chloride (PVC). Polystyrene is one of the components in municipal solid waste, which contributes $10 \%$ of total plastic wastes. The vast quantity of waste polystyrene is expected to expand even further due to the high demand for polystyrene products in our everyday life (Istadi et al. 2010). Polystyrene is a by-product of petrochemical industries, which is generally made up of styrene monomers. Commercially, it can be applied in households, packaging, constructions, computer cabinets and cold drink cups (Selvaganapathy et al. 2020).

Several disposal techniques can impel plastic waste generation, but they have some limitations. Still, plastic wastes are extensively being landfilled. These techniques have adverse effects on the environment and release harmful gases to the earth (Pinto et al. 1999). Recycling is the best solution to the environmental challenges in achieving sustainable manufacturing; this turns waste materials into financial, environmental and societal resources (Patni et al. 2013). The plastic waste can be recycled through different recycling techniques such as mechanical reprocessing, mechanical recycling, chemical recycling and incineration (Selvaganapathy \& Muthuvelayudham 2019). Most recycling methods are expensive, energy-consuming and often end up in producing low-grade products excluding chemical recycling; it can significantly reduce disposal cost. Chemical recycling method is an eco-friendly approach to

\footnotetext{
*Corresponding author: selvachemengg@gmail.com
} 
treat plastic waste containing carbonaceous materials (Patni et al. 2013).

The thermal and catalytic cracking's are the two different approaches of chemical recycling, which have been recognized as ideal approaches for converting waste feedstock to fuel (Lerici et al. 2015 and Sarker\& Rashid 2013). Thermal cracking involves the decomposition of plastic wastes by applying heat $\left(350-900{ }^{\circ} \mathrm{C}\right)$ in an oxygen de-void condition. In contrast, catalytic cracking involves the presence of catalysts, which demonstrated as an effective conversion technique of waste plastic into useful fuel products at moderate temperatures and short retention time when compared with thermal cracking (Patni et al. 2013, Jouhara et al. 2018 and Garieb Alla \& Alhag Ali 2014). FCC, fly ash, bentonites, dolomites, zeolites and silica alumina-based catalysts were extensively used in the catalytic cracking process (Miandad et al. 2016). However, the catalyst synthesis can enrich the catalyst's catalytic activity. Babajide et al. (2010) studied the fly ash catalyst impregnation with an aqueous $\mathrm{KNO}_{3}$ solution and found the impregnated fly ash catalyst produced a maximum conversion than raw fly ash material. Hence, the investigated fly ash catalyst is synthesized with 20 wt.\% of aqueous $\mathrm{KNO}_{3}$; which could be a novel approach of this investigation.

Despite numerous researches being studied for the liquid fuel production from waste plastics through cracking but still, it remains inconclusive of the appropriate product composition of pyrolysis products. Only a few researchers have been focused on modeling and simulation studies by programming software such as Matlab, Pro Sim, Chem-Cadd, Aspen Hysys and Aspen Plus. The importance of this programming software like the Aspen Hysys is used to imitate the performance analysis of any chemical process. In the Aspen Hysys simulator, the product distribution of any chemical process was anticipated by operating parameters and chemical reactions. Aspen Hysys is a computer-based simulator, which relates to the physical correlations of any chemical unit process such as material and energy balances (Selvaganapathy et al. 2019). Based on these observations, a few investigations only have modelled the waste plastic thermal cracking process and no more research presented for catalytic cracking process (Adeniyi et al. 2018 and Moses et al. 2018). Hence, this research work is aimed to simulate the polystyrene catalytic cracking process using the Aspen Hysys simulator and. Also, the experimental investigation of polystyrene catalytic cracking process was performed with different ratios of impregnated fly ash and polystyrene materials. At the end of experiment, the produced liquid fuel was characterized using FTIR analysis, GC/MS analysis and physico-chemical property analysis.

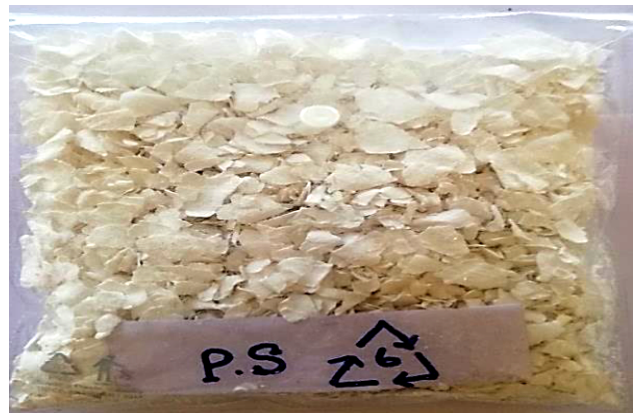

Fig.1 Polystyrene waste after shredding

\section{Materials andMethods}

\subsection{Plastic Material}

The polystyrene-type waste plastic was selected for the catalytic cracking experiments (Fig 1). Initially the raw polystyrene was shredded into a small size. The shredded polystyrene plastic was then appropriately cleaned and dried to remove unwanted dirties. The polystyrene degradation stages were assessed using a simultaneous Thermogravimetric with derivative thermogravimetric analysis (TGA-DTG).

\subsection{Catalyst Material}

The coal-fly ash material was selected and which is available in local markets. To promote raw catalyst's catalytic activity, incipient impregnation method was used for fly ash catalyst synthesis. Precisely, $10 \mathrm{~g}$ of fly ash (Fig 2) was added gradually with specified amount of aqueous $\mathrm{KNO}_{3}(20$ wt.\%) and mixed until homogeneity. After the homogeneous reaction, the impregnate was dried in a hot air oven for $8 \mathrm{~h}$ at $100^{\circ} \mathrm{C}$ and then cooled down to the ambient temperature. The final impregnate was again calcinated at $500{ }^{\circ} \mathrm{C}$ for $5 \mathrm{~h}$. A grey coloured crystal form of the heterogeneous catalyst appeared after calcination (Fig 3 ). The raw and impregnated fly ash catalyst were characterized by a scanning electron microscopy (SEM) with energy dispersive spectroscopy (EDS) using an FEIQuanta 250 analyzer. The morphological structure of the catalyst was performed using an SEM analysis, where the atomic composition was identified by EDS.

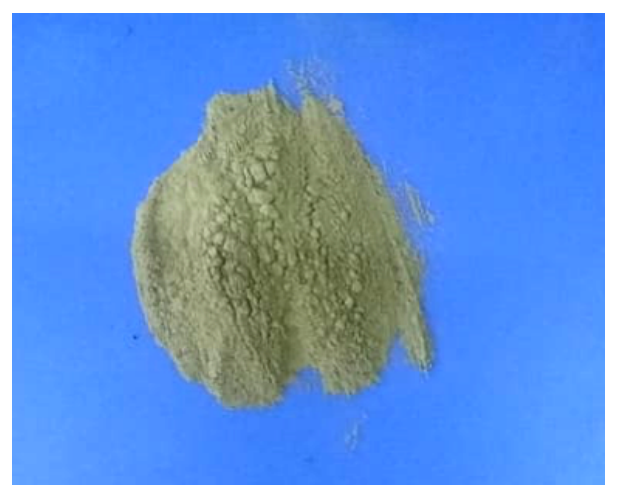

Fig.2 Raw fly ash before impregnations

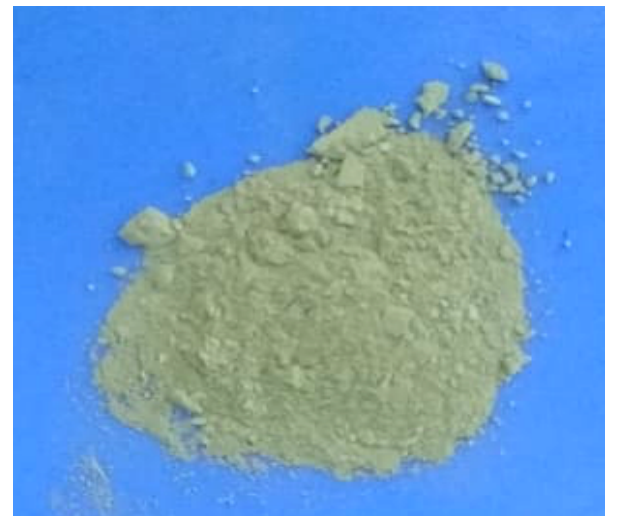

Fig.3 Impregnated (20 wt.\% $\left.\mathrm{KNO}_{3}\right)$ fly ash catalyst 


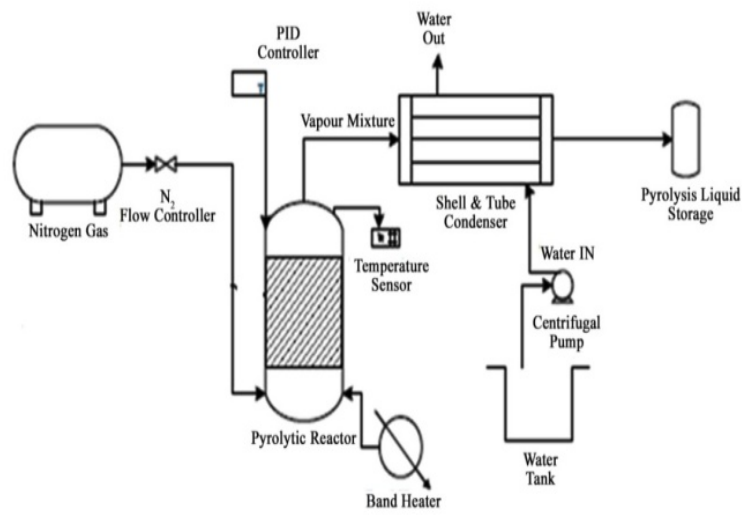

Fig.4 Experimental setup for the catalytic cracking of polystyrene

\subsection{Experimental investigation of Polystyrene Catalytic cracking process}

Pilot-scale equipment was used for the catalytic cracking of waste polystyrene (Fig.4). This set-up comprises the pyrolytic reactor, shell and tube condenser, band heater, PID (Proportional - Integral - Derivative) controller, temperature sensor, and purging gas (nitrogen) cylinder. The steps involved in catalytic cracking of waste polystyrene have described below;

The pyrolytic reactor with $2 \mathrm{~kg}$ capacity was employed for the polystyrene catalytic cracking process, and a PID controller controlled the reacting system. The nitrogen purging $(10 \mathrm{~mL} / \mathrm{min})$ in the reactor prevents even the trace amount of oxygen gases. About 1:10 (0.2), 1:4 (0.25), 1:2 (0.50) and 3:4 (0.75) ratios of polystyrene with fly ash catalyst (Impregnated ) were loaded to the reactor; the whole reacting system was heated at the temperatures between $400-500^{\circ} \mathrm{C}$ using a band heater. After the cracking reaction proceeded, the vapour mixtures coming from the reactor were then condensed through the shell and tube condenser. The liquid condensate was collected in the liquid collection point, while the condensed pyro gas was collected from the gas collector. At the end of cracking experiments, a mass balance of pyrolysis products could be made using standard mass balance analysis.

\subsection{Characterization of liquid fuel}

The liquid fuel obtained from the polystyrene catalytic cracking process was characterized by FT-IR spectra, GC/MS analyses and Physico-chemical property analysis. FT-IR analysis was carried out using a Perkin-Elmer spectrum (Agilent Technologies Cary-630 FTIR) in the spectral region between $400-4000 \mathrm{~cm}^{-1}$. GC/MS (Agilent Technologies) analysis indicates hydrocarbons present in a liquid sample with respect to different retention times. The capillary column was fused with a capillary tube having dimensions of $30 \mathrm{~m}$ of length, $0.25 \mathrm{~mm}$ of inner diameter and film thickness of about $0.5 \mu \mathrm{m}$. $\mathrm{He}_{2}$ gas was used as a carrier gas and its flow rate was maintained at $1.5 \mathrm{~mL} / \mathrm{min}$. The column oven temperature was maintained at $40^{\circ} \mathrm{C}$ for $5 \mathrm{~min}$, and then increased to $325^{\circ} \mathrm{C}$ at a heating rate of $10^{\circ} \mathrm{C} / \mathrm{min}$, held for $10 \mathrm{~min}$. The mass spectra and the data samples were interpreted and matched with standard MS programs with mass scan 35$528 \mathrm{EI}+$ data format centroid, scanning time $0.25 \mathrm{~s}$. Gas chromatography with mass spectrometry (GC/MS) analysis indicates different hydrocarbon chain compounds with a different retention time of pyrolysis liquid fuel. The Physico-chemical properties of liquid fuel were analyzed using ASTM standards.

\subsection{Development of simulation model for the polystyrene catalytic cracking process}

The assumption to make the most feasible model for the polystyrene catalytic cracking are;

$>$ The model is a steady-state model.

$>$ Isobaric process and Isothermal conditions.

$>$ The solid char residue contains carbon contents only.

Aspen Hysys V9 simulator employed the simulation of catalytic cracking of polystyrene to value-added products. In this Simulink tool contains property and simulation environments. The components used for the polystyrene catalytic cracking process were chosen from the property environment, as tabulated in Table 1 . The thermodynamic model (fluid package) was also chosen from the property environment and which is used to evaluate the stoichiometric coefficient and other physical parameters of all components. Peng-Robinson's model was chosen for the thermodynamic model which is expressed in Eq. (1) (Adeniyi et al. 2018 and Moses et al. 2018). The heterogeneous catalytic reaction was chosen as a reaction set and the developed reaction set was attached to the developed fluid package. Once the reaction set was agreed, the simulation environment was moved. Unit operation blocks were picked from the palette section of the simulation environment.

$$
p=\frac{R T}{V-b}-\frac{a(T)}{V(V+b)+b(V-b)}
$$

$$
\begin{gathered}
19 \mathrm{C}_{8} \mathrm{H}_{8} \stackrel{\Delta}{\rightarrow} \mathrm{H}_{2}+\mathrm{CH}_{4}+\mathrm{C}_{2} \mathrm{H}_{6}+\mathrm{C}_{2} \mathrm{H}_{4}+\mathrm{C}_{3} \mathrm{H}_{6}+\mathrm{C}_{3} \mathrm{H}_{8}+\mathrm{C}_{4} \mathrm{H}_{10} \\
+\mathrm{C}_{8} \mathrm{H}_{16}+\mathrm{C}_{16} \mathrm{H}_{32}+\mathrm{C}_{28} \mathrm{H}_{56}+85 \mathrm{C}
\end{gathered}
$$

In the Aspen Hysys, the model was developed based on the process flow sheet of Adeniyi et al. (2018). The reactor block was chosen from the column section and the condenser was selected from the common section in the palette. A brief description of unit operations used for catalytic cracking of polystyrene along with their section containing in the palette is described in Table 2.

Table 1

Component selection in component list environment (GariebAlla\& Ali. 2014)

\begin{tabular}{ccc}
\hline Component & Chemical formula & CAS number \\
\hline Styrene & $\mathrm{C}_{8} \mathrm{H}_{8}$ & $100-42-5$ \\
Hydrogen & $\mathrm{H}_{2}$ & $1333-74-0$ \\
Methane & $\mathrm{CH}_{4}$ & $74-82-8$ \\
Ethane & $\mathrm{C}_{2} \mathrm{H}_{6}$ & $74-84-0$ \\
Ethylene & $\mathrm{C}_{2} \mathrm{H}_{4}$ & $74-85-1$ \\
Propene & $\mathrm{C}_{3} \mathrm{H}_{6}$ & $115-07-1$ \\
Propane & $\mathrm{C}_{3} \mathrm{H}_{8}$ & $74-98-6$ \\
n-butane & $\mathrm{C}_{4} \mathrm{H}_{10}$ & $106-97-8$ \\
Cyclo-octane & $\mathrm{C}_{8} \mathrm{H}_{16}$ & $292-64-8$ \\
1-Hexadecene & $\mathrm{C}_{16} \mathrm{H}_{32}$ & $629-73-2$ \\
1-Octocosene & $\mathrm{C}_{28} \mathrm{H}_{56}$ & $18835-34-2$ \\
Carbon & $\mathrm{C}$ & $7440-44-0$ \\
\hline
\end{tabular}


Citation: Thambiyapillai, S. and Ramanujam, M. (2021) An Experimental Investigation and Aspen HYSYS Simulation of Waste Polystyrene Catalytic Cracking Process for the Gasoline Fuel Production. Int. Journal of Renewable Energy Development, 10(4),891-900, doi: 10.14710/ijred.2021.33817

P a g e $\mid 894$

Table 2

Brief description of blocks used catalytic cracking of polystyrene along with their section containing in the palette

\begin{tabular}{|c|c|c|}
\hline Block Name & $\begin{array}{c}\text { Section in } \\
\text { palette }\end{array}$ & Description \\
\hline $\begin{array}{l}\text { Heating } \\
\text { Element }\end{array}$ & Common & $\begin{array}{c}\text { To heat the reactor for } \\
\text { the burning waste } \\
\text { plastics. }\end{array}$ \\
\hline $\begin{array}{l}\text { Pyrolysis } \\
\text { reactor }\end{array}$ & Column & $\begin{array}{l}\text { Simulates the pyrolysis } \\
\text { process of waste plastic. }\end{array}$ \\
\hline Condenser & Common & $\begin{array}{l}\text { To convert vapour into } \\
\text { gas and liquid. }\end{array}$ \\
\hline
\end{tabular}

\section{Results and discussions}

\subsection{Thermal analysis of polystyrene}

Fig. 5 shows the polystyrene thermal degradation at various heating rates viz., $5,10,15$ and $20^{\circ} \mathrm{C} / \mathrm{min}$. With an increase in the heating rate 5 to $20{ }^{\circ} \mathrm{C} / \mathrm{min}$, the degradation temperature increases from 355.24 to 474.98 ${ }^{\circ} \mathrm{C}$. The DTG curve infers that $18 \%$ weight loss was recorded at $370.14{ }^{\circ} \mathrm{C}$ and $99.99 \%$ degradation occurred at $474.98^{\circ} \mathrm{C}$. The degradation pattern is seen as single stage process from the single peak for the polystyrene wastes, which observation is also reported in several researches (Phetyim \& Art 2018 and Nisar et al., 2019). Further no significant variations were observed in the regime $<350^{\circ} \mathrm{C}$ and $>480{ }^{\circ} \mathrm{C}$. Nisar et al. (2019) reported that the polystyrene degradation occurred in the temperature between $387-428^{\circ} \mathrm{Cat}$ various heating rates.

\subsection{Catalyst Characterization}

The synthesis of the raw catalyst is required to enhance the catalytic activity by increasing pore size, pore-volume and surface area (Adil, 2013). Fig.6 shows the morphological structure of the raw fly ash, which is observed as smooth with larger spherical shapes and irregular. The structure of $20 \mathrm{wt} . \% \mathrm{KNO}_{3}$ impregnated fly ash looks like a micro-sphere, typically between 2-10 $\mu \mathrm{m}$, can be represented as a hollow cenosphere. The impregnation effect on fly ash catalyst destructed the structural morphology and removed the undesirable earth materials. Olivia et al. (2019) reported the impregnation effect on fly ash has destructed their physical structure and eliminated the unwanted impurities.

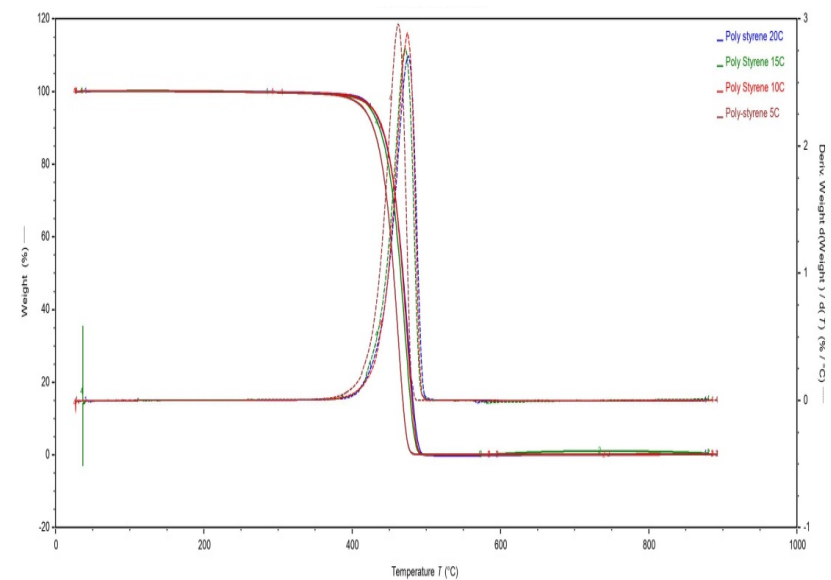

Fig. 5 TGA-DTG curves of polystyrene degradation at 5, 10, 15 and $20^{\circ} \mathrm{C} / \mathrm{min}$
Table 3

The elemental composition of raw and impregnated fly ash catalysts

\begin{tabular}{ccc}
\hline Elements & $\begin{array}{c}\text { Raw fly } \\
\text { ash }\end{array}$ & $\begin{array}{c}\text { 20 wt.\% impregnated fly } \\
\text { ash }\end{array}$ \\
\hline $\mathrm{O}, \mathrm{K}$ & 50.76 & 56.91 \\
$\mathrm{Na}, \mathrm{K}$ & 0.92 & 0 \\
$\mathrm{Mg}, \mathrm{K}$ & 1.59 & 1.55 \\
$\mathrm{Al}, \mathrm{K}$ & 12.70 & 9.72 \\
$\mathrm{Si}, \mathrm{K}$ & 20.07 & 13.79 \\
$\mathrm{~S}, \mathrm{~K}$ & 1.37 & 0 \\
$\mathrm{~K}, \mathrm{~K}$ & 0.63 & 8.47 \\
$\mathrm{Ca}, \mathrm{K}$ & 7.32 & 6.56 \\
$\mathrm{Fe}, \mathrm{K}$ & 4.63 & 2.99 \\
\hline
\end{tabular}

The Energy Dispersive Spectrometer (EDS) analyses used to compare the both the raw and synthesized catalyst's elemental compositions. The elemental composition of the raw and impregnated fly ash catalysts are given in Table 3 and their spectral regions are shown in Fig. 7 respectively. The raw fly ash has numerous earth metals such as $\mathrm{Ca}, \mathrm{Fe}, \mathrm{Na}, \mathrm{Mg}$, and $\mathrm{K}$. The weight percentages of the major component in raw fly ash were found to be $50.76 \%$ of $\mathrm{O}, 12.70 \%$ of $\mathrm{Al}, 20.07 \%$ of $\mathrm{Si}, 7.32 \%$ of $\mathrm{Ca}$, and $4.63 \%$ of $\mathrm{Fe}$ with a minor component of $0.92 \%$ of $\mathrm{Na}, 1.59 \%$ of $\mathrm{Mg}, 1.375$ of $\mathrm{S}$ and $0.63 \%$ of $\mathrm{K}$. The impregnated fly ash with $20 \mathrm{wt} . \% \mathrm{KNO}_{3}$ catalysts had the elemental composition - $56.91 \%$ of O, $1.55 \%$ of $\mathrm{Mg}, 9.72 \%$ of $\mathrm{Al}, 13.79 \%$ of $\mathrm{Si}, 6.56 \%$ of $\mathrm{Ca}$, and $2.99 \%$ of $\mathrm{Fe}$. Further, it was observed that the pre-treatment has improved the number of essential elements such as $\mathrm{Si}\left(\mathrm{SiO}_{2}\right), \mathrm{Al}\left(\mathrm{Al}_{2} \mathrm{O}_{3}\right)$, $\mathrm{Mg}(\mathrm{MgO}), \mathrm{Ca}$ and $\mathrm{K}$ by eliminating undesirable sulfur and sodium. Olivia et al., (2017) observed the impregnation effect on fly ash has enhanced the desirable $\mathrm{Si}, \mathrm{Al}, \mathrm{Mg}, \mathrm{Ca}$ and $\mathrm{K}$ compositions with undesirable $\mathrm{S}$ and $\mathrm{Na}$ reductions

\subsection{Factors influencing the polystyrene catalytic cracking process}

In order to optimize the operating conditions, the waste polystyrene were catalytically cracked with impregnated fly ash catalyst by varying the reaction temperature from 400 to $500^{\circ} \mathrm{C}$ and reaction time from 45 90 min under nitrogen atmosphere. The major influencing parameters were discussed as follows;

\subsubsection{Effect of Catalyst to feedstock ratio on Liquid Yield}

To know the appropriate quantity of catalyst for maximizing the liquid yield, the fly ash catalyst and polystyrene plastics were cracked in various ratios, viz., 1:10, 1:4, 1:2 and 3:4 under optimum conditions. The resultant plot is presented in Fig.8 and the maximum liquid yield (88.4\%) was obtained at 1: 4 ratios. The liquid product yield was decreased with an increase in the fly ash amount 1:10, 1:2 and 3:4 ratios and thus ratios are not significant for the polystyrene catalytic cracking process, which is coincidence with many researchers (Cleetus et al., 2013 and Panda and Singh, 2013). Panda and Singh (2013) performed thermo-catalytic process and the maximum 
liquid yield (87.5\%) was observed at 1: 3 ratios. However, Cleetus et al. (2013) were found the 1:4 ratios as an optimum condition of producing maximum liquid fuel.

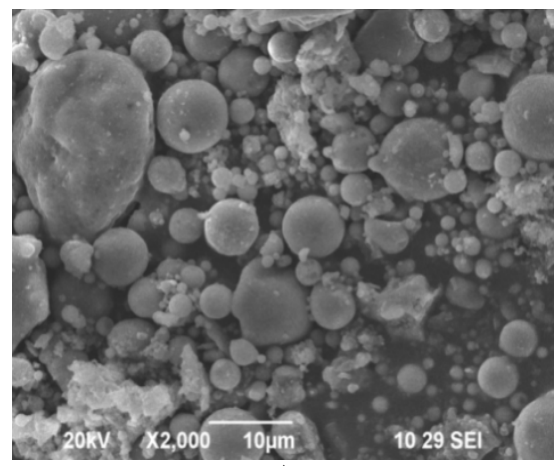

a)

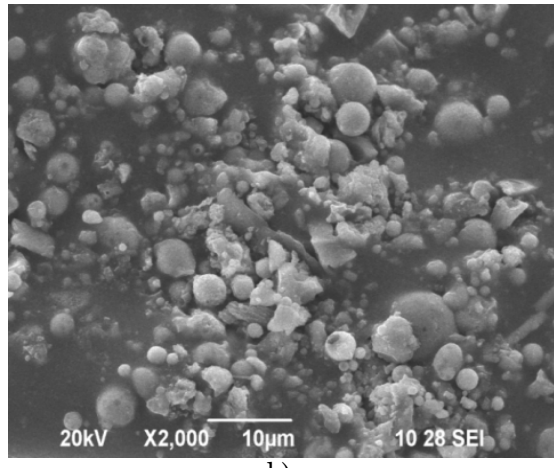

b)

Fig.6 SEM images of a) raw fly ash catalyst andb) impregnated fly ash catalyst
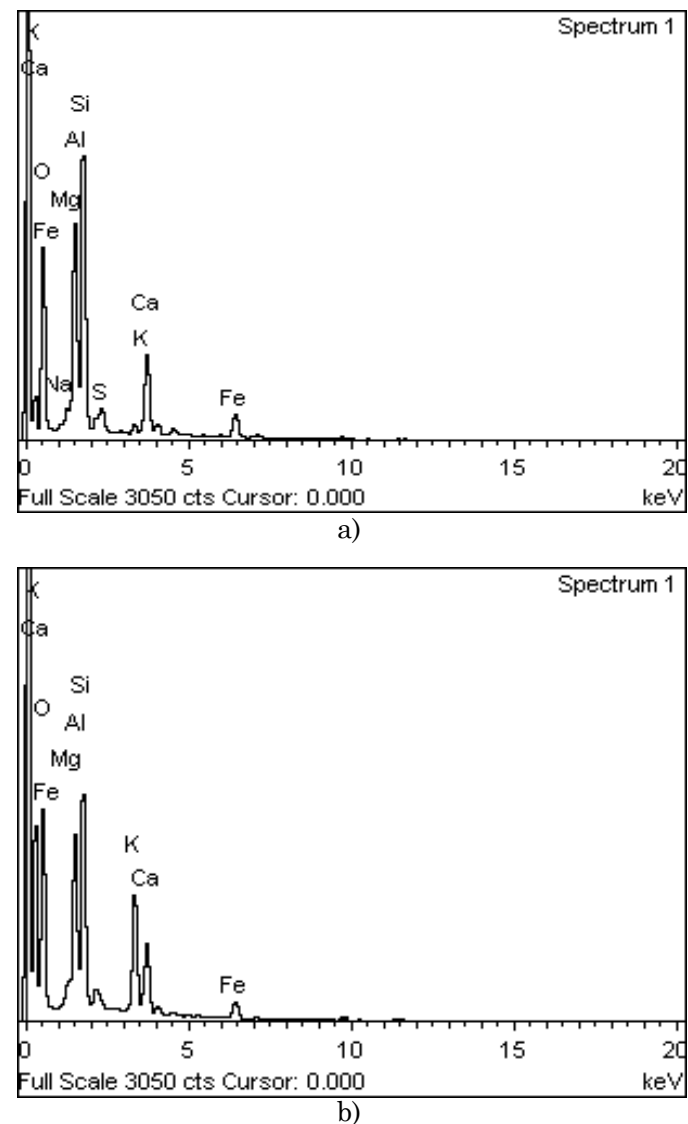

Fig.7 EDS analysis of a) raw fly ash catalyst and b) impregnated fly ash catalysts

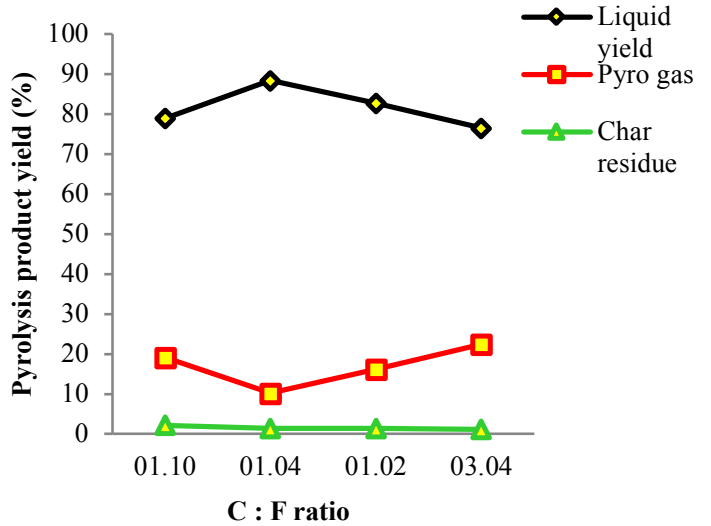

Fig.8 Effect of C: F ratio on polystyrene catalytic cracking process

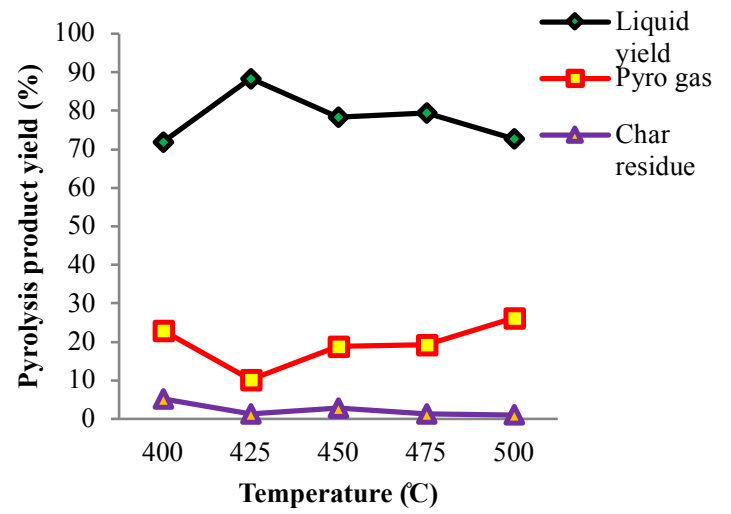

Fig.9 Effect of temperature on polystyrene catalytic cracking process

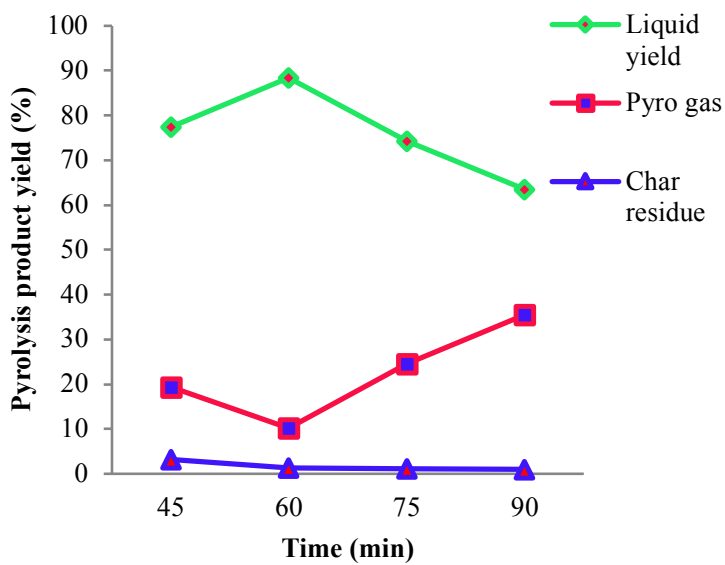

Fig.10 Effect of time on polystyrene catalytic cracking process

\subsubsection{Effect of Temperature on Liquid Yield}

In the fly ash cracking of polystyrene, the operating temperature significantly influences the pyrolysis product yields. In order to study the optimum reaction temperature, the polystyrene was catalytically degraded in the temperature between $400{ }^{\circ} \mathrm{C}-500{ }^{\circ} \mathrm{C}$ for maximizing 
liquid product yield under optimum reaction conditions. The resultant plot is portrayed in Fig.9. The maximum amount of liquid yield $(88.4 \%)$ was obtained at $425^{\circ} \mathrm{C}$ and at $450{ }^{\circ} \mathrm{C}$ it reduced to $78.4 \%$. Beyond the $425{ }^{\circ} \mathrm{C}$, the liquid yield reduced to $79.5 \%$ and $72.8 \%$ for the $475{ }^{\circ} \mathrm{C}$ and $500{ }^{\circ} \mathrm{C}$ respectively. Adil (2013) conducted HDPE catalytic cracking with Co-Mo catalyst in the temperature ranging between $410-450^{\circ} \mathrm{C}$ and the maximum liquid product (78\%) was yielded at $440{ }^{\circ} \mathrm{C}$. However, Panda and Singh (2013) reported the liquid yield has increased with the temperature above $400{ }^{\circ} \mathrm{C}$ and decreased with the temperature beyond $500{ }^{\circ} \mathrm{C}$.

\subsubsection{Effect of Time on Liquid Yield}

The effect of reaction time on polystyrene catalytic cracking process is shown in Fig.10. In the fly ash cracking of polystyrene, the maximum liquid yield was obtained at $60 \mathrm{~min}$ as $88.4 \%$. Beyond the $60 \mathrm{~min}$ of reaction time was preferable for pyro gas production. At 75 min of reaction time, the product yields were found as $24.6 \%$ of pyro gas, $74.2 \%$ of liquid yield and $1.2 \%$ of char residue and the reaction time of $90 \mathrm{~min}$ the product yields were found as $35.5 \%$ of pyro gas, $63.5 \%$ of liquid yield and $1.0 \%$ of char residue respectively. Sonawane et al. (2015) reported the maximum conversion of liquid yield $(86.4 \%)$ was observed at $65 \mathrm{~min}$ of reaction time from polypropylene catalytic cracking process.

\subsection{Characterization of liquid fuel}

The liquid fuel quality was checked using physicochemical property, GCMS and FTIR analysis. The characterization of liquid fuel was discussed in this section.

\subsubsection{Physico-Chemical Properties of liquid fuel}

The liquid fuel density was $0.825 \mathrm{~g} / \mathrm{cc}$, which is almost equal to the commercial diesel density $(0.807)$ value. The kinematic viscosity of liquid fuel was found as $1.4 \mathrm{cSt}$, which having a similar kinematic viscosity of gasoline fuel
(1.17 cSt) and lower than the diesel fuel (1.9-4.1 cSt) values (Sharuddin et al. 2016). Pour point was used to examine the suitability of fuel for low-temperature installations (Johnson et al. 2015). The pour point was -3 ${ }^{\circ} \mathrm{C}$, which may be acceptable for a most geographic region (Kumar \& Singh 2013). The cloud point temperature was found as $+9{ }^{\circ} \mathrm{C}$, which had a lower cloud point than the conventional diesel $\left(-12^{\circ} \mathrm{C}\right)$. This reveals that the produced liquid fuel was easy to handle in all the regions. Flashpoint used to analyse the fire hazards of fuel and the flashpoint temperature was determined as $36^{\circ} \mathrm{C}$. This is a lower flashpoint value than the commercial diesel $\left(52^{\circ} \mathrm{C}\right)$ and close value with commercial gasoline $\left(42{ }^{\circ} \mathrm{C}\right)$ value (Sharuddin et al. 2016). Gross calorific value (GCV) was found as $44.68 \mathrm{MJ} / \mathrm{kg}$, which is higher than the commercial diesel (43.0) and commercial gasoline (42.5).

\subsubsection{FTIR analysis of liquid fuel}

Fig.11 shows the FTIR spectra of liquid fuel obtained from the fly ash cracking of polystyrene under optimum reaction conditions. The presence of alkene is detected at $3077 \mathrm{~cm}^{-1}$ in a strong appearance with respect to $=\mathrm{C}-\mathrm{H}$ stretching vibrations. C-H stretching vibrations in strong appearance at $2976 \mathrm{~cm}^{-1}$ shows that the presence of alkane groups. The presence of aldehyde is detected at $2728 \mathrm{~cm}^{-1}$ in a strong appearance with respect to $\mathrm{C}-\mathrm{H}$ stretching vibrations. The presence of aromatic compounds is detected at $1577 \mathrm{~cm}^{-1}$ and $1460 \mathrm{~cm}^{-1}$ in weak appearance with $\mathrm{C}=\mathrm{C}$ stretching vibrations. The presence of alkyl halide is detected at $1357 \mathrm{~cm}^{-1}$, and $1277 \mathrm{~cm}^{-1}$ in a strong peak with $\mathrm{C}-\mathrm{F}$ stretching vibration. $=\mathrm{C}-\mathrm{H}$ Bend stretching is detected at $821 \mathrm{~cm}^{-1}$ indicates that the presence of alkene. The presence of alkyl halide is detected at wavenumbers of $584 \mathrm{~cm}^{-1}$ with C-I stretching vibrations. Also, it was inferred from the FTIR analysis, the fuel consists of aliphatic and olefinic compounds with a major constituent of aromatic compounds. Lee et al. (2002) reported the FTIR analysis of liquid fuel obtained from polystyrene catalytic cracking consists more than $99 \%$ of aromatic groups with a minor quantity of paraffin's. This is due to the high stability of the aromatic compounds which inhibit the further secondary cracking.

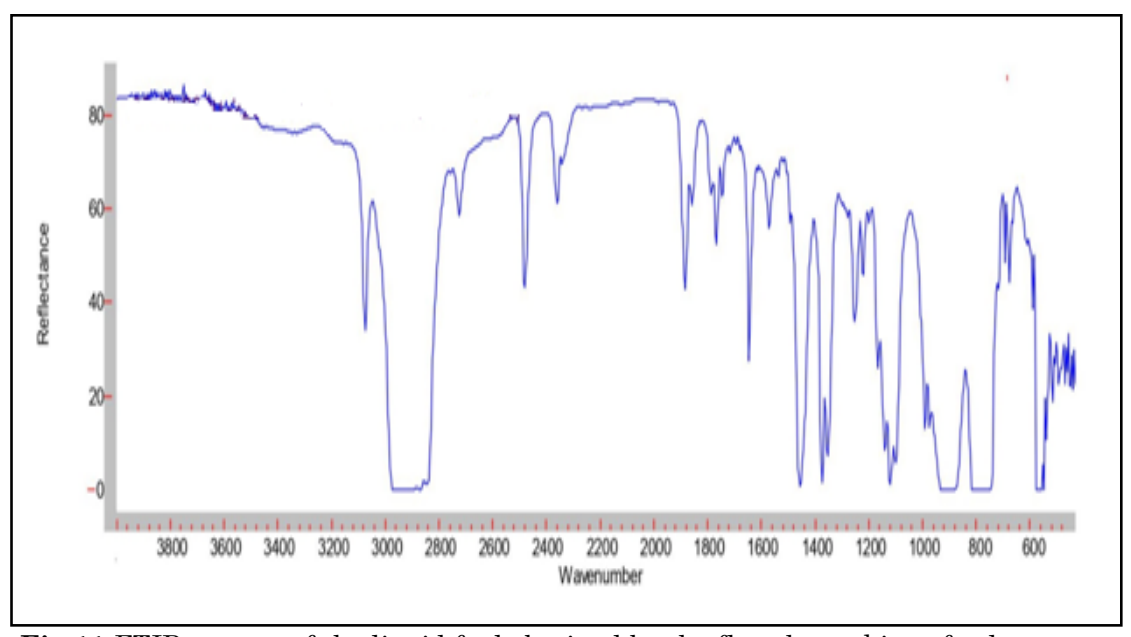

Fig.11 FTIR spectra of the liquid fuel obtained by the fly ash cracking of polystyrene 


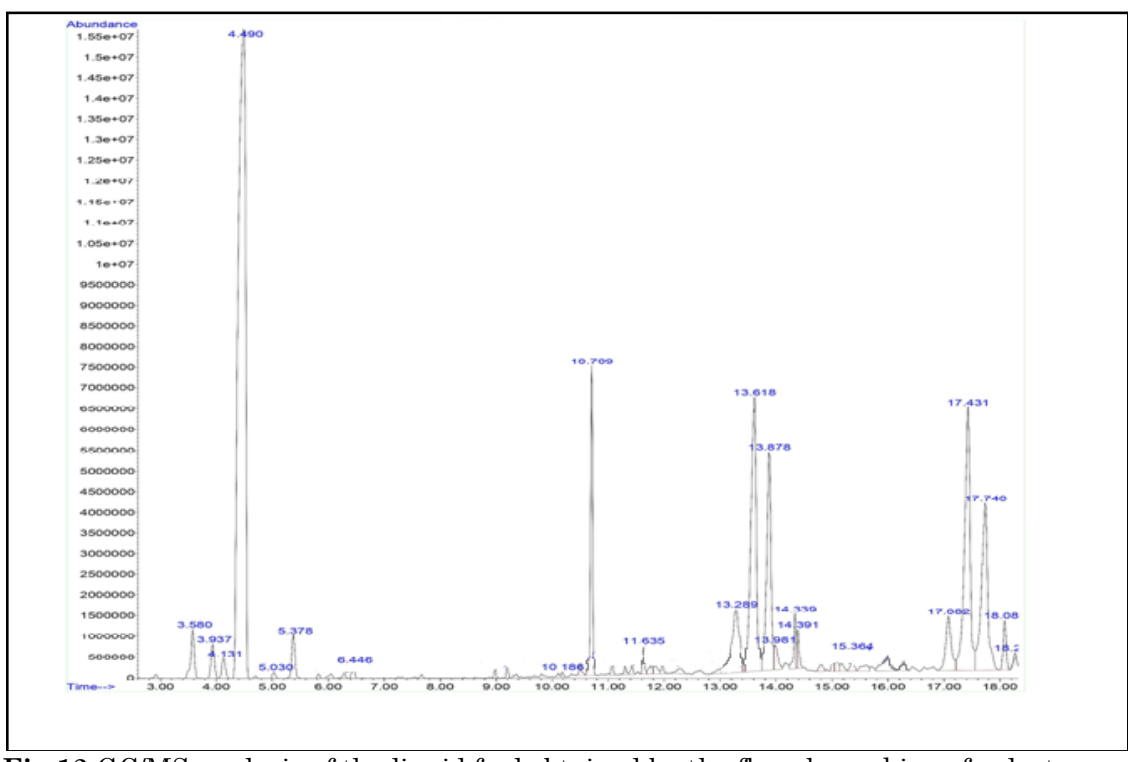

Fig.12 GC/MS analysis of the liquid fuel obtained by the fly ash cracking of polystyrene

\subsubsection{GC/MS analysis of liquid fuel}

The GC/MS analysis of the liquid fuel is shown in Fig.12. The assay report according to the retention time 3.580 , the compound is Pentane, 2-methyl-, retention time 4.487 compound is $\mathrm{n}$-Hexane, the retention time 10.707 compound is 2,4-Dimethyl-1-heptene, retention time 13.416 compound is 3 -Tetradecene (E)-, retention time 13.877 compound is Tetradecane, the retention time 17.427 compound is 1 -Pentadecene, the retention time 17.743 compound is Octane, 4-methyl-, the retention time 18.276 compound is Dodecyl isobutyl carbonate and few more hydrocarbons with smaller peak. The appeared hydrocarbon chain compounds mostly contain mixed fractions of gasoline, kerosene and diesel range products carbon number of $\mathrm{C}_{3}-\mathrm{C}_{24}$. These findings are in good association with the reported literature (Nisar et al., 2020). Nisar et al., (2020) reported the catalytically cracked liquid oil from the polystyrene contains petroleum products with $\mathrm{C}_{3}-\mathrm{C}_{24}$ carbon numbers.

\subsection{Simulation output of the polystyrene catalytic cracking model}

Prior to the assembling of model blocks for the catalytic cracking process, the operating condition of each block was introduced. At a flow rate of $100 \mathrm{~kg} / \mathrm{h}$, the operating temperature at $425{ }^{\circ} \mathrm{C}$ and inert atmospheric conditions, the polystyrene was inlet into the reactor through the material stream. The vapor fractions were produced as a top product, while the char residue was produced as a bottom product in the reacting system. The desirable vapor fractions are then fed into the condensing system to acquire high-grade products such as petroleum fuel.

\subsubsection{Material and energy balance of the pyrolysis reactor}

The simulation environment of polystyrene catalytic cracking process is shown in Fig.13. The reactor block's operating conditions are tabulated in Table 4. The material stream polystyrene in a reactor block as a solidstate and its vapor fraction is zero. The polystyrene was converted into char residue and vapor fraction at various temperature ranges. Likewise, the mass flow rate of the vapor fraction is more than the char residue flow rate. Moreover, the material stream polystyrene's heat flow was equally distributed to the heat flow of vapor fraction and char residue. Furthermore, the catalytic cracking was an endothermic reaction and its heat of reaction at $25^{\circ} \mathrm{C}$ was found as $1.89 \times 10^{5} \mathrm{~kJ} / \mathrm{k} \mathrm{mol}$.

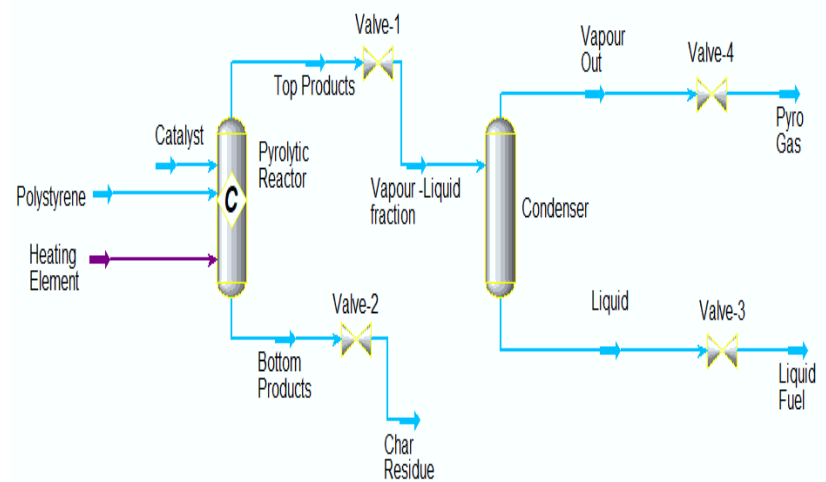

Fig.13 Simulation environment of the catalytic cracking of polystyrene

Table 4

Operating conditions of the reactor for catalytic cracking of Polystyrene

\begin{tabular}{|c|c|c|c|}
\hline Operating variable & Polystyrene Fed & Vapor liquid fraction & Char residue \\
\hline Vapor fraction & 0 & 1 & 0 \\
\hline Reaction temperature $\left[{ }^{\circ} \mathrm{C}\right]$ & 425 & 410 & 30 \\
\hline Relative pressure [atm] & 1 & 1 & 1 \\
\hline Feed flow rate $[\mathrm{kg} / \mathrm{h}]$ & 100 & 98.74 & 1.26 \\
\hline Heat flow $[\mathrm{kJ} / \mathrm{h}]$ & 375.50 & 336.40 & 39.10 \\
\hline
\end{tabular}


Citation: Thambiyapillai, S. and Ramanujam, M. (2021) An Experimental Investigation and Aspen HYSYS Simulation of Waste Polystyrene Catalytic Cracking Process for the Gasoline Fuel Production. Int. Journal of Renewable Energy Development, 10(4),891-900, doi: 10.14710/ijred.2021.33817

$\mathrm{P}$ a g e 1898

Table 5

Component flow rate around the reactor of Polystyrene catalytic cracking

\begin{tabular}{cccc}
\hline Components & Polystyrene Fed (kg/h) & Vapor liquid fraction $\mathbf{( k g / h )}$ & Char residue $(\mathbf{k g} / \mathbf{h})$ \\
\hline $\mathrm{C}_{8} \mathrm{H}_{8}$ & 100 & 0 & 0 \\
$\mathrm{H}_{2}$ & 0 & 3.848 & 0 \\
$\mathrm{CH}_{4}$ & 0 & 0.614 & 0 \\
$\mathrm{C}_{2} \mathrm{H}_{6}$ & 0 & 0.770 & 0 \\
$\mathrm{C}_{2} \mathrm{H}_{4}$ & 0 & 0.688 & 0 \\
$\mathrm{C}_{3} \mathrm{H}_{6}$ & 0 & 0.0032 & 0 \\
$\mathrm{C}_{3} \mathrm{H}_{8}$ & 0 & 0.062 & 0 \\
$\mathrm{C}_{4} \mathrm{H}_{10}$ & 0 & 0.032 & 0 \\
$\mathrm{C}_{8} \mathrm{H}_{16}$ & 0 & 35.85 & 0 \\
$\mathrm{C}_{16} \mathrm{H}_{32}$ & 0 & 46.33 & 0 \\
$\mathrm{C}_{28} \mathrm{H}_{56}$ & 0 & 10.54 & 0 \\
$\mathrm{C}$ & 0 & 0 & 1.26 \\
\hline
\end{tabular}

Table 6

Operating conditions of the condenser for catalytic cracking of polystyrene

\begin{tabular}{cccc}
\hline Operating variable & Vapor liquid fraction & Pyro gas & Liquid fuel \\
\hline Vapor fraction & 1 & 1 & 0 \\
Reaction temperature $\left[{ }^{\circ} \mathrm{C}\right]$ & 410 & 35 & 38 \\
Relative pressure $[\mathrm{atm}]$ & 1 & 1 & 1 \\
Feed flow rate $[\mathrm{kg} / \mathrm{h}]$ & 98.74 & 5.14 & 93.6 \\
Heat flow $[\mathrm{kJ} / \mathrm{h}]$ & 336.4 & 22.1 & 314.30 \\
\hline
\end{tabular}

Table 5 represents the flow rate of reactant and product stream of catalytic cracking in a reactor block. According to the results, it was inferred that the mass of reactant is equally balanced with the mass of products leaving. Then, the results are a good association with the conservation law of mass.

\subsubsection{Material and energy balance of the condenser}

The operating conditions and energy flow around the condenser during condensation of vapor fraction into desired products are tabulated in Table 6. From Table 6, the vapor mixtures from the reactor were then fed into the condenser in which the vapor fraction is 1 whereas the vapor fraction of liquid fuel is 0 and 1 of pyro gas. Moreover, it was observed from the results, the temperature of the liquid fuel and the pyro gas is not as much as that of the vapor fraction temperature.

Table 7 expresses that component flow rate around the condenser during the condensation. At the end of the simulation, the product yield distribution was found to be $93.6 \%$ of liquid fuel, $5.14 \%$ of pyro gas and $1.26 \%$ of char residue individually. It was inferred that the simulated model for the catalytic cracking is substantial to fit the experimental data in terms of liquid fuel conversion. These investigations are in reasonable agreement with earlier researches (Adeniyi et al., 2018 and Garieb Alla \&
Ali, 2014). Adeniyi et al. (2018) simulated the LDPE thermal cracking process and the maximum conversion of liquid product $(92.88 \%)$ was obtained at $450{ }^{\circ} \mathrm{C}$ and inert atmospheric conditions. Garieb Alla \& Ali (2014) simulated the thermal cracking of various waste plastics and results were found as $95.2 \%$ of liquid yield and $4.6 \%$ of non-condensed gases.

\section{Conclusions}

The polystyrene catalytic cracking experiment has been conducted in a pilot-scale pyrolytic reactor and the optimum operating conditions were found as $425^{\circ} \mathrm{C}, 45 \mathrm{~min}$ of reaction time, and 1:4 of catalyst to polystyrene feed ratio, for maximum liquid yield of $88.4 \%$. Furthermore, the steady-state simulation of polystyrene catalytic cracking process was modelled through Aspen Hysys simulator and the simulated model produced $93.6 \%$ of liquid yield. Comparisons between the experimental and simulated results show that the error is $5.2 \%$. These variations are provided reasonable agreement between the experimental and simulated results. The developed simulation mode can be a manual for scale-up studies and will give an aspiration to the researcher's for understanding the actual product ranges. 
Table 7

Component flow rate around the condenser for catalytic cracking of polystyrene

\begin{tabular}{cccc}
\hline Components & Vapor liquid fraction $\mathbf{( k g / h )}$ & Pyro gas $\mathbf{( k g / h )}$ & Liquid fuel (kg/h) \\
\hline $\mathrm{C}_{8} \mathrm{H}_{8}$ & 0 & 0 & 0 \\
$\mathrm{H}_{2}$ & 3.848 & 2.99 & 0 \\
$\mathrm{CH}_{4}$ & 0.614 & 0.608 & 0 \\
$\mathrm{C}_{2} \mathrm{H}_{6}$ & 0.770 & 0.764 & 0 \\
$\mathrm{C}_{2} \mathrm{H}_{4}$ & 0.688 & 0.682 & 0 \\
$\mathrm{C}_{3} \mathrm{H}_{6}$ & 0.0032 & 0.0032 & 0 \\
$\mathrm{C}_{3} \mathrm{H}_{8}$ & 0.062 & 0.061 & 0 \\
$\mathrm{C}_{4} \mathrm{H}_{10}$ & 0.032 & 0.032 & 0 \\
$\mathrm{C}_{8} \mathrm{H}_{16}$ & 35.85 & 0 & 36.22 \\
$\mathrm{C}_{16} \mathrm{H}_{32}$ & 46.33 & 0 & 46.72 \\
$\mathrm{C}_{28} \mathrm{H}_{56}$ & 10.54 & 0 & 10.66 \\
$\mathrm{C}$ & 0 & 0 & 0 \\
\hline
\end{tabular}

\section{Acknowledgments}

I pay my deep sense of gratitude to our respected Chairman and Member Secretary of Tamilnadu Pollution Control Board, Guindy, Chennai-32 for permitting me to research in the waste plastic recycling.

\section{References}

Adeniyi, A., Eletta, O., \& Ighalo, J. (2018). Computer Aided modelling of Low Density Poly Ethylene (LDPE) Pyrolysis to produce Synthetic Fuels. Nig. J. of Tech., 37 (4), 945-949. https://doi.org/10.4314/njt.v37i4.12

Adil K. (2013). Studying the Utilization of Plastic waste by Chemical Recycling Method. Open J. of Appl. Sci., 3 (1), 413420. http://dx.doi.org/10.4236/ojapps.2013.37051

Amoodi, N., Kannan, P., Shoabi, A., \& Srinivasakannan, C. (2013). Aspen plus simulation of polyethylene gasification under equilibrium conditions. Chem. Eng. Comm., 200, 977992. https://doi.org/10.1080/00986445.2012.715108

Babajide, O., Leslie, P., Nicholoss, M., Bamikole, A.,, \& Farouk, A. (2010). Use of Coal Fly ash as a catalyst in the Production of Biodiesel. Petroleum \& Coal., 52(4), 261-272. http://hdl.handle.net/10566/574

Cleetus,C., Thomas, S. and Varghese, S.. (2013), Synthesis of Petroleum-Based Fuel from Waste Plastics and Performance analysis in a CI Engine,. Jour. of Ener., 1, 1-10. https://doi.org/10.1155/2013/608797

Garieb Alla, M \& Ali, A. (2014). Simulation and Design for process to convert plastic waste to liquid fuel using Aspen Hysys program. Integer. J. Engg. Res. Tech., 1(6), 270-274. https://www.researchgate.net/publication/270441063

Istadi, Suherman, S., \& Buchori., L. (2010). Optimization of reactor temperature and catalyst weight for plastic cracking to fuels using response surface methodology. Bull. Chem. React. Eng. Catal., $\quad$ 5, $103-111$. https://doi.org/10.9767/bcrec.5.2.797.103-111

Johnson, O., Igbokwe, Olisaemeka, C., Nwwufo, \& Chidiebere Nwaiwu. (2015). Effects of blend on the properties, Performance and emission of palm kernel oil biodiesel. Bio fuels., 6, 1-18. https://doi.org/10.1080/17597269.2015.1030719

Jouhara, H., \& Ahmad, D., Van den Boogaert, Katsou, Simons, S., Spencer, N. (2018). Pyrolysis of domestic based feedstock at temperatures up to $300^{\circ} \mathrm{C}$. Therm. Sci. Eng. Prog., 5, 117143. http://bura.brunel.ac.uk/handle/2438/15556
Kumar, S., \& Singh, R. (2013). Thermolysis of High-density Polyethylene to petroleum products. Hindawi pub. Corp., 1, 17. https://doi.org/10.1155/2013/987568

Lee, S., Yoon, J., Kim, J., \& Park P.W,(2002), Degradation of polystyrene using Clinoptilolite catalysts. J. of appl. and $\begin{array}{llll}\text { anal. } & \text { pyrol. } & 64, & \text { 71-83. }\end{array}$ https://www.infona.pl/resource/bw meta1.element.elsevier.

Lerici, LC., Renzini, MS., \& Pierella, LB. (2015). Chemical catalysed recycling of polymers: catalytic conversion of PE, PP and PS into fuels and chemicals over H-Y. Proc. Mater. Sci., 8, 297-303. https://ri.conicet.gov.ar/handle/11336/10959

Miandad, R.,. Barakat, M., Asad, Aburiazaiza, S., \& Rehan, M. (2016).Catalytic pyrolysis of plastic waste: A review. Pro. Saf. Environ. Prot., 102, 822-838. https://doi.org/10.3389/fenrg.2019.00027

Ministry of Housing and Urban Affairs, (2019). Annual Report of Plastic Waste Management - Available online on: http://mohua.gov.in/

Moses, Erhianoh, C., \& Edward A.. (2018). Modelling and Simulation of Waste Plastic Power Plant A Theoretical Framework. Amer. J. of Chem.Eng., 6(5), 94-98. https://doi.org/10.11648/J.AJCHE.20180605.13

Nisar, J., Ghulam, A., Afsal S., Munawar I., Rafaqat, A, Sirajuddin, Farooq, A., Raqeeb, U, \& Salim, A. (2019). Fuel productions from Waste polystyrene via pyrolysis: Kinetics and products distribution, Was Manag., 88, 236-247. https://doi.org/10.1016/j.wasman.2019.03.035

Nisar, J., Ghulam, A., Afsal, S., Naeem, A., Zahoor, H., Ahsan, S., Ejaz, A., Munawar, I., Syed, T., \& Muhammad Raza Shah, (2020).Pyrolysis of polystyrene waste for recovery of combustible hydrocarbons using copper oxide as catalyst, Waste Manag. \& Res, 1, pp. 1-9. https://doi.org/10.1177/0734242x20904403

Panda, A., \& Singh, RK.(2013), Experimental Optimization of Process for the Thermo-catalytic Degradation of Waste Polypropylene to Liquid fuel, Adv. in Ener. Engg., 1 (3), 7484. https://www.researchgate.net/publication/286226581.

Patni, N., Shah, P., Agarwal, S., \& Singhal, P. (2013). Alternative strategy for conversion of waste plastic to fuels. ISRN renew. Ener., 1, 1-7. https://doi.org/10.1155/2013/902053

Phetyim, N.,\& Sommai Pivsa-Art, S. (2018). Prototype Copyrolysis of used lubricant oil and Mixed plastic waste to produce a diesel-like fuel. Energies., 11 (2973), 1-11. https://doi.org/10.3390/en11112973

Pinto, F., Costa, P., Gulyurtlu, I., \& Cabrita, I. (1999). Pyrolysis of plastic wastes 2. Effect of catalyst on product yield. J. of Anal. and Appl. Pyro., 51, 57-71. 
Citation: Thambiyapillai, S. and Ramanujam, M. (2021) An Experimental Investigation and Aspen HYSYS Simulation of Waste Polystyrene Catalytic Cracking Process for the Gasoline Fuel Production. Int. Journal of Renewable Energy Development, 10(4),891-900, doi: 10.14710/ijred.2021.33817

$\mathrm{P}$ a g e $\mid 900$

https://www.infona.pl/resource/bwmeta1.element.elsevier63112775-9325-373c-befa-7a89b9928f61

Olivia, R., Novesar, J, Syukri, A., \& Yenny, A. (2017). The Utilization of Dolomite as catalyst in Biodiesel Production, Rasayan J. Chem., $10 \quad$ (1), 160-164. http://www.rasayanjournal.co.in/admin.

Sarker, M., \& Rashid. M., (2013). Mixture of LDPE, PP and PS Plastic solid waste into Fuel by Thermolysis Process. Inter. J. of Eng. and Tech. Res.,1, 1-16. http://www.ijeatr.org/

Saxena, A,, Sharma, H., and Girish Rathi. (2017), Conversion of Waste Plastic to Fuel: Pyrolysis-An Efficient Method: A Review, International Conference on New and Renewable Energy Resources for Sustainable Future, Swami Keshvan and Institute of Technology, Management and Gramothan, Jaipur (India)

Sharuddin, S., Faisal, A., \& Wan, D. (2016). A review on pyrolysis of plastic wastes, Ener. conver. Manag., 115, 308-326. http://dx.doi.org/10.1016/j.enconman.2016.02.037
Selvaganapathy, T., \& Muthuvelayudham, R. (2019). Aromatic Liquid Hydro-Carbon Fuel (ALHF) production from the waste plastic using pyrolytic reactor under thermal degradation. Inter. J. of Man. IT \& Engg.9, 98-141. https://www.ijmra.us/2019ijmie_april.php

Selvaganapathy, T., Muthuvelayudham, R., \& Jayakumar, M. (2020). Process parameter optimization study on thermolytic polystyrene liquid fuel using response surface methodology (RSM). Mat. Today. Proceed., 26, 2729-2739. https://doi.org/10.1016/j.matpr.2020.02.572

Selvaganapathy, T., Muthuvelayudham, R., \& Jeyakumar, M. (2019). Steady-state Simulation of Plastic Pyrolysis Process using Aspen Hysys V9 Simulator. Int. J. Recent Tech. and Engg.,8, 2206-2211. $\quad$ https://www.ijrte.org/wp/v8i4/D7885118419.

Sonawane, Y., Shindikar, M., \& Khaladkar, M., (2015). Use of Catalyst in Pyrolysis of Polypropylene waste into Liquid Fuel. Int Res. J. of Env. Sci., 4(7), 24-28. https://www.researchgate.net/publication/317429097 